\title{
Isolation and phylogenetic analysis of polyphosphate accumulating organisms in water and sludge of intensive catfish ponds in the Mekong Delta, Vietnam
}

\author{
Le Quang Khoi ${ }^{1,2, *}$, Cao Ngoc Diep ${ }^{1,2, *}$ \\ ${ }^{1}$ Tien Giang Applied Research \& Technological Science Service Center, Vietnam; Dept. Microbiology Biotechnology, Can Tho City, \\ Vietnam \\ ${ }^{2}$ Science and Technology Department, Tien Giang province, Vietnam; Biotechnology R\&D Institute, Can Tho University, Can Tho City, \\ Vietnam
}

\section{Email address:}

khoi62031101@student.ctu.edu.vn(L. Q. Khoi), cndiep@ctu.edu.vn(C. N. Diep)

\section{To cite this article:}

Le Quang Khoi, Cao Ngoc Diep. Isolation and Phylogenetic Analysis of Polyphosphate Accumulating Organisms in Water and Sludge of Intensive Catfish Ponds in the Mekong Delta, Vietnam. American Journal of Life Sciences. Vol. 1, No. 2, 2013; pp. 61-71.

doi: $10.11648 /$ j.ajls.20130102.17

\begin{abstract}
Polyphosphate accumulating organisms were isolated from water and sludge samples of intensive catfish ponds in the Mekong Delta, Vietnam. The Results of estimation of intracellular polyphosphate concentration conducted on each of monocultures indicated that the content of intracellular polyphosphate varied from $2 \mathrm{mg} / 1$ to $148.1 \mathrm{mg} / \mathrm{l}$ after 6 days of incubation in the medium. Of 191 isolates, twenty-one have uptake and store intracellular phosphate from 19.6 to $148.1 \mathrm{mg} / \mathrm{l}$. They have shaped like a rods and short rods or cocci, a few of them were slightly curved or straight or curved rods. The majority of them are gram-positive (76.2\%) and the remains are gram-negative. The partial 16S rRNA genes of these isolates were sequenced and compared with bacterial 16S rRNA genes in Genbank using BlastN Program. Phylogenetic tree was constructed on the basic 16S rRNA gene sequences demonstrating the population of high phosphate accumulating bacteria obtained from samples of catfish ponds were affiliated with four major bacterial lineages. Twenty-one bacteria isolates from samples of catfish ponds included in four classes: Bacilli, Actinobacteria, Beta-proteobacteria, Gamma-proteobacteria. The majority of the strains showed excess phosphate accumulation. Strains related to Bacillus sp. were dominant bacteria group constituted up to $52.4 \%$ of all identified isolates, but high phosphate accumulating bacteria are Burkholderia vietnamiensis TVT003L within class Beta-proteobacteria, Acinetobacter radioresistens TGT013L within Gamma-proteobacteria and Arthrobacter protophomiae VLT002L within class Actinobacteria. Methyl blue Loeffler's staning and electron microscopy examination confirmed that the bacteria had stored polyphosphate granules intracellularly.
\end{abstract}

Keywords: Polyphosphate Accumulating Organisms, Polyphosphate, Phosphate Removal, Catfish Pond, Bacilli, Actinobacteria

\section{Introduction}

Mekong Delta $\left(8^{0} 33^{\prime}-10^{0} 55^{\prime} \mathrm{N}, 104^{0} 33^{\prime}-106^{0} 50^{\prime} \mathrm{E}\right)$, South Vietnam, covers $36,000 \mathrm{~km}^{2}$ accounting for over $4 \%$ of the catchment area and are the final drainage of the Mekong River Basin. The Mekong River, with a mean discharge volume of $15,000 \mathrm{~m}^{3} / \mathrm{s}$, traverses $4,880 \mathrm{~km}$ through six countries, and divides into seven major branches when it enters the Delta, approximately $170 \mathrm{~km}$ from the South China Sea (1). The Mekong Delta with a population of 17.42 million (in 2004), is popularly referred to as the food basket of Vietnam; for example, it accounted for nearly half of the national food volume (in 2000 totaling 17.5 million tons), 55\% of the national fishery and fruit production and $61 \%$ of the national food export value (2). The culture of catfish, Pangasianodon hypophthalmus, also known as "ca tra" in Vietnamese, in the Mekong Delta, Vietnam can be considered as a unique aquatic farming system in many ways. Catfish culture is predominantly in deep earthen ponds (average $4-4.5 \mathrm{~m}$ ), mostly along the two main branches (Tien Giang and Hau Giang) of the Mekong River (Figure 1). The farm size ranged from 0.2 to 30 ha with a mean of 4.09 ha. The frequency distribution of the yield in tone/ha/crop corresponded to a normal distribution curve, 
where $75 \%$ of the farms yielded 300 tones/ ha/crop or more (3). The sector accounted for 687,000 and 1,094,879 tone production, in 2007 and 2008, respectively, with over 95\% of the produce destined for export to over 100 countries (4).

De Silva et al., (2010) reported that, the total amount of nito (N) and phospho (P), based on values for commercial feeds, discharged from catfish farming in the Mekong Delta in 2007 and 2008 were estimated to be 31,602 tons $\mathrm{N}$ and 9,893 tons $\mathrm{P}$, and 50,364 tons $\mathrm{N}$ and 15,766 tons $\mathrm{P}$, respectively (4). Although, not all of $\mathrm{N}$ and $\mathrm{P}$ are discharged directly into the Mekong River, as an of proportion of the water used for catfish farming as well as the sludge is diverted to other agricultural farming systems, and some nutrients will be retained in the sludge of ponds or taken up by other biota in the environment. It is suggested that the play an important role of bacteria in accumulation of phosphorous in the water catfish ponds.

Polyphosphate accumulating organisms (PAOs) is known as the microorganisms to absorb free phosphate in the environment and assimilate them as intracellular polyphosphate (poly-P) particles. This process was viewed as enhanced biological phosphorus removal (EBPR) in wastewater treatment systems $(5,6,7)$. Biochemical mechanism of this process is the metabolic process in the cell of PAOs. In anaerobic conditions, they uptake volatile fatty acids (VFAs) and assimilate them into poly-hydroxyalkanoates (PHAs), energy required for the synthesis was generated from mainly part of the hydrolysis of intracellular poly-P particles $(6,8)$. In subsequently the aerobic process, they absorb and assimilate extracellular phosphate into intracellular poly-P particles; the energy required for this process is the catabolism of PHAs. PHAs be seen as carbon and energy source for cell growth, poly-P is a source of phosphorus and sources of energy such as ATP is required for cell survival of microorganisms in environmental conditions as poor nutrition. Through the process of anaerobic and aerobic microbial cells taken excess extracellular phosphate needs for their growth and development. This excess amount of phosphate that they accumulate as intracellular poly-P and is removed from water with their biomass $(6,8)$. These microorganisms and their biochemical mechanisms are applied to remove dissolved phosphate in wastewater, the critical factor in the eutrophication of water soluble phosphate rich waste.

Many studies have focused on the isolation of this microbial group responsible for EBPR. Formerly the target bacteria were Acinetobacter spp. which was subsequently shown not to be responsible for EBPR. Many other pure cultures were isolated from EBPR processes, but none of them have exhibited all the characteristics which EBPR sludge should posses (6). Isolations of PAOs remain essential, because experiments with pure cultures will provide substantial information about the microbiological and biochemical aspects of EBPR process. In many cases, the key characteristics which are lacking in these isolates are the acetate metabolisms. Furthermore, PAOs are to be relatively slow growing $(9,10)$. The cultivation time for forming colony was after incubating the cell for 1 - 3 weeks (6). Additionally, the enzymes responsible for the anaerobic substrate uptake and poly-P utilization appear to be inducible (10) and that alternating anaerobic-aerobic conditions may be necessary. The primary carbon sources extracellularly for PAOs thriving and growth are short-chain fatty acids (SCFAs) as acetate, succinate, ethanol (11, 6, 12, 13, 14). Although many attempts to isolate PAOs responsible for EBPR are fail or exhibit insufficient all the characteristics of EBPR process, with the development of molecular biotechnology, a number of modern techniques such as DAP (15), FISH (12) are support to reveal groups of microorganisms that are important role to remove phosphate dissolved in the wastewater treatment planning operated highly effective phosphate removal activities such as Acinetobacter sp., Rhodocyclus sp., Tetrasphaera sp., Microlunatus phosphovorus. In addition, some studies isolated a few other bacteria that can also accumulate poly-P as Bacillus sp., Staphylococcus sp., Pseudomonas sp., Enterobacter sp. (16). This proves that group of microorganisms capable of poly-P accumulation diverse about species.

Studies regarding identification of PAOs have been reported. Identity through isolation process, describe morphology of the bacteria associated with determine the presence of poly-P particles by intracellular staining Loeffler'methyl blue. Identification of bacteria by the modern molecular biology techniques such as FISH, DAP, $16 \mathrm{~S}$ rRNA sequencing. Studies of the population diversity are also based on molecular biology techniques. The genetic studies responsible for intracellular poly-P accumulation (17, 18, 19), The studies the genetic diversity based on polyphosphate kinase gene 1 (20) with different primers.

One of the methods to identify bacteria that are able to accumulate poly-P more or less is qualitative and quantitative analysis of intracellular poly-P particles. Several techniques can be used as methyl blue staining of poly-P (5). Buzoleva et al., (2006) demonstrated that most of the bacterial poly-P is alkali-soluble, especially at the preliminary stage of cell growth (21). Eixler et al., (2005) using several different methods for extraction of intracellular poly-P of Chlorella vulgaris and Synechocystic sp. The results clearly indicate that $\mathrm{NaOH}$ and hot water treatment followed by filtration of the extracts are suitable to obtain a cell free suspension of intact poly-P granules without hydrolysing the polymers (22).

However, the study of PAOs as their role in the EBPR process, identification of the PAOs, diversity of PAOs, PAOs metabolism...mainly performed in sequencing batch reactors. But, there were not many studies of PAOs in water and sludge of catfish pond. Therefore, the purpose of the study was to isolate and analyze the phylogeny of poly-P accumulating organisms in water and sludge of catfish ponds in the Mekong Delta, Vietnam based on 16S rRNA sequences. This research is essential to understanding about their population structure in order to screen and select poly-P accumulating bacteria using treatment soluble phosphorus in waste of catfish pond. 


\section{Material and Methods}

\subsection{Site Description}

Sludge and waters were obtained from catfish ponds. Seventy composite samples (sludge and water) were taken from 10 provinces in the Mekomg Delta, Vietnam (Figure1) included Dong Thap, An Giang, Tien Giang, Kien Giang, Can Tho, Vinh Long, Ben Tre, Hau Giang, Tra Vinh and Soc Trang province and excepted Long An, Bac Lieu and Ca $\mathrm{Mau}$ as none of the largest freshwater aquaculture industries . The samples were stored at $10^{\circ} \mathrm{C}$ during transit and processed immediately.

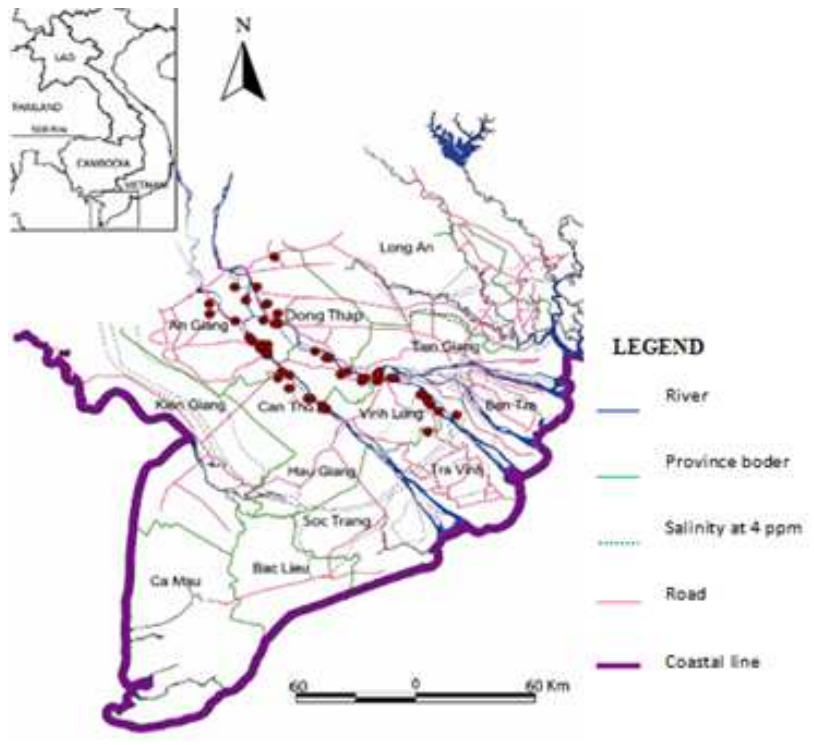

Figure 1. The geographic map and location of the main catfish farming areas in the Mekong Delta, Vietnam (3)

\subsection{Media}

The media used for isolating micro-organisms are composed of the agar-based culture medium and agar-based subculture medium.

Components for the agar-based culture medium (g/l): 5.0 Acetate, 0.5 Glucose, 0.5 Succinate, $0.02 \mathrm{NH}_{4} \mathrm{Cl}, 0.088$ $\mathrm{KH}_{2} \mathrm{PO}_{4}, 0.5$ Pepton, $0.01 \mathrm{MgSO}_{4} .7 \mathrm{H}_{2} \mathrm{O}, 0.005 \mathrm{CaCl}_{2}$ and $0.5 \mathrm{ml}$ of a trace element solution (23). The trace element solution contained (g/l): $1.5 \mathrm{FeCl}_{3} \cdot 6 \mathrm{H}_{2} \mathrm{O}, 0.15 \mathrm{H}_{3} \mathrm{BO}_{3}, 0.03$ $\mathrm{CuSO}_{4} .5 \mathrm{H}_{2} \mathrm{O}, 0.18 \mathrm{KI}, 0.12 \mathrm{MnCl}_{2} .4 \mathrm{H}_{2} \mathrm{O}, 0.06 \mathrm{Na}_{2} \mathrm{MoO}_{4}$. $2 \mathrm{H}_{2} \mathrm{O}, 0.12 \mathrm{ZnSO}_{4} .7 \mathrm{H}_{2} \mathrm{O}, 0.15 \mathrm{CoCl}_{2} .6 \mathrm{H}_{2} \mathrm{O}, 10$ EDTA. Agar $(20 \mathrm{~g} / \mathrm{l}), \mathrm{pH}$ was adjusted to 7.0 with $\mathrm{NaOH} 1 \mathrm{M}$.

Components for the agar-based subculture medium $(\mathrm{g} / \mathrm{l})$ : the same components for the agar-based culture medium, but none of carbon source including $0.02 \mathrm{NH}_{4} \mathrm{Cl}, 0.088 \mathrm{KH}_{2} \mathrm{PO}_{4}$, 0.5 pepton, $0.01 \mathrm{MgSO}_{4} .7 \mathrm{H}_{2} \mathrm{O}, 0.005 \mathrm{CaCl}_{2}$ and $0.5 \mathrm{ml}$ of a trace element solution (23). Agar (20 g/l). pH was adjusted to 7.0 with $\mathrm{NaOH} 1 \mathrm{M}$.

\subsection{Isolation of Bacteria}

Cultivation-based techniques were used to gain insight into the abundance and species composition of bacterial communities, and to reveal the poly-P accumulation of bacteria. Serial dilutions $\left(10^{-2}\right.$ to $\left.10^{-4}\right)$ of composite samples were prepared. Dilutions $(0.05 \mathrm{ml})$ were aseptically plated on the agar-based culture medium. Plates were incubated at $30^{\circ} \mathrm{C}$ for 5 days. Bacterial colonies were differentiated on the basis of colony morphology and pigmentation. Colonies were subculture on the agar-based subculture medium plates by striking technique and re-incubated at $30^{\circ} \mathrm{C}$ for 5 days. This isolation process carries out in shifts of the agar-based culture medium to the agar-based subculture medium until monocultures were obtained. Monocultures were culture on the agar-based culture medium slant in the test-tube $(12 \mathrm{ml})$ and incubated at $30^{\circ} \mathrm{C}$ for 4 days following by stored $10^{\circ} \mathrm{C}$ in refrigerator.

\subsection{Culture Medium and Enrichment Culture for Phosphate Uptake Studies}

Inoculums were prepared by plated onto the agar-based culture medium with a isolate stored and incubated at $30^{\circ} \mathrm{C}$ for 6 days. Inoculums were picked and inoculated to $4 \mathrm{ml}$ of broth medium tube sterilization at $30^{\circ} \mathrm{C}$ for 6 days (on shaker at $160 \mathrm{r} \mathrm{min}^{-1}$ ). The following medium was used throughout this study: $5 \mathrm{~g} / \mathrm{l}$ sodium acetate, $0.5 \mathrm{~g} / \mathrm{l} \mathrm{MgSO} 4,7 \mathrm{H}_{2} \mathrm{O}$, $0.18 \mathrm{~g} / 1 \mathrm{KNO}_{3}, 0.25 \mathrm{~g} / 1 \mathrm{KH}_{2} \mathrm{PO}_{4}$ (16) with supplemented components as $0.5 \mathrm{~g} / 1$ pepton, $0.5 \mathrm{~g} / 1$ yeast extract and 0.5 $\mathrm{ml} / \mathrm{l}$ of a trace elements solution containing (23).

\subsection{Extraction of Poly-P}

Extraction of intracellular poly-P was carried out according to the method of Eixler et al., (2005) (22). Cell suspension ( $4 \mathrm{ml}$ ) was centrifuged $(10,000 \mathrm{rpm} ; 10 \mathrm{~min})$, the supernatant discarded and the pellet re-suspended in $4 \mathrm{ml}$ $\mathrm{NaOH} 0.2 \mathrm{~N}$ at $30^{\circ} \mathrm{C}$ (on shaker at $160 \mathrm{r} \mathrm{min}^{-1}$ ) for 20 hours in order to extracting poly-P. All extracts were filtered (Sartorius Stedim CE, Cat. No. 17598 and 0,45 $\mu \mathrm{m}$ ) for reject cells.

\subsection{Quantification of Intracellular Poly-P}

Subsamples of this suspension were used for chemical analysis. The supernatant was dividing into two parts. The first fraction was measured as soluble reactive phosphorus with the molybdenum blue method (24). This fraction was named $\mathrm{pp} 1$ in the following. The second fraction was hydrolyzed in the present of $1 \mathrm{M} \mathrm{HCl}$ for $10 \mathrm{~min}$ at $100^{\circ} \mathrm{C}$. Amount of labile phosphorus in all poly-P fractions was determined again as described above. This fraction was named pp2 (total extractable cellular phosphorus). The difference between pp 2 and pp1 should represent the content of poly-P.

\subsection{Characterization of the Isolate}

Phenotype and motility of PAOs were observed and described by light microscopy.

\subsubsection{Gram Staining}

The morphology of the isolates was determined 
following Gram staining and examined via light microscopy.

\subsubsection{Transmission Electron Microscopy (TEM)}

TEM examination was carried out according to the method of Boswell et al., (2001) (25). Cell suspensions (1 ml) were centrifuged $\left(5,000 \mathrm{rpm} ; 5 \mathrm{~min}\right.$ at $\left.10^{\circ} \mathrm{C}\right)$, twice washed with distilled water and enclosed in $1.5 \%$ agarose. Biomass samples were fixed by re-suspension in $1.5 \%(\mathrm{w} / \mathrm{v})$ glutaraldehyde solution in water (Sigma-Alorich) at $10^{\circ} \mathrm{C}$ for $2 \mathrm{~h}$, recentrifuging and washed twice with distilled water. The samples were post-fixed with $1 \%(\mathrm{v} / \mathrm{v})$ osmium tetroxide solution in water for electron microscopy (Sigma-Alorich) for $4 \mathrm{~h}$ at $20^{\circ} \mathrm{C}$, and then briefly rinsed. The samples were dehydrated sequentially in an ethanol/water series (v/v): $70 \%, 90 \%$ and $100 \%$ for $10 \mathrm{~min}$ at each gradation. After dehydration, the samples were embedded in Epon 812 epoxy resin. The epoxy mixed samples were polymerized in an oven at $60^{\circ} \mathrm{C}$ for $16 \mathrm{~h}$. The hardened samples were then trimmed and sectioned to $70 \mathrm{~nm}$ using a diamond knife on an Ultra microtone (Powertome X-RMC, Boeckeler). Ultrathin sections were transferred to the surface copper grid and stained in $1 \%(\mathrm{w} / \mathrm{v})$ Methyl blue solution ( $\mathrm{pH} 3.0)$ in $70 \%$ ethanol for 10 seconds (5). After thorough rinsing in water, the sectioned samples were dried and examined using a JEOL-1400 TEM (accelerating voltage $100 \mathrm{kV}$ ).

\subsection{Phylogenetic Identification of PAOs Isolated}

A whole cell direct lysis was used to extract DNA as described previously (26). Universal eubacterial primers $27 \mathrm{~F}$ and $1492 \mathrm{R}$ (27) were used for PCR to amplify $16 \mathrm{~S}$ rRNA gene from the genomic DNA. The PCR was carried out occording to Ivanov et al., (2005) (28). in a $25 \mu$ (total volume) reaction mixture containing $100 \mathrm{ng}$ purified template DNA, 1X PCR buffer, $2 \mathrm{mM} \mathrm{MgCl} 2,0.2 \mathrm{mM}$ each of dNTP, $0.2 \mu \mathrm{M}$ each of forward and reverse primers and 1U Taq polymerase. After initial denaturation at $95^{\circ} \mathrm{C}$ for 5 min, followed by 30 cycles of thermal cycling (denaturation at $95^{\circ} \mathrm{C}$ for $1 \mathrm{~min}$, primer annealing at $57^{\circ} \mathrm{C}$ for $0.45 \mathrm{~min}$, extension at $72^{\circ} \mathrm{C}$ for $1.5 \mathrm{~min}$ ), a final extension at $72^{\circ} \mathrm{C}$ for 7 min. PCR products were run on $1,2 \%$ agarose gels with $1 \mathrm{X}$ TAE buffer at $90 \mathrm{~V}$ for $1.5 \mathrm{~h}$, and bands visualized with ethidium bromide. Gels were viewed and photographed with Bio-Rad Universal HoodII.

PCR amplicons were purified with Qiagen PCR purification kits. For the sequencing of 16S rRNA gene, the nucleotide sequence of each amplicon was determined using the dideoxy chain termination chemistry and the ABI model 310A sequencer (Applied Biosystems, USA).

For each determined sequence, the Basic Local Alignment Search Tool (BLAST) search program was queried for initial determination of the nearest phylogenetic neighbour sequences in the database maintained by National Centre for Biotechnology Information (NCBI) (National Institutes of Health, USA). The reference sequences were chosen from representatives of the nearest neighbour groups, as well as the sequences from taxa representing several different bacteria phyla. All sequences were multi-aligned by CLUSTALW (1.6) program. The phylogenetic tree were constructed from evolutionary distances using MEGA5 program (29). For the maximum likelihood method was used. Bootstrap confidence values were obtained with 500 resamplings. The bootstrap values indicated the resampling percentage that supported a specific branching pattern.

The identification of stains was based on closest species on the phylogenetic tree and classified to various classes, families according to Bergey's Manual of Systematic Bacteriology, 2nd edition (New York: Springer) (30). The bacteria screened from the different sampling sites were given symbols (code name) based on the source of isolation (i.e., AG: An Giang, note on table 3).

\section{Results and Discussion}

\subsection{Isolation and Characterization of PAOs}

Isolation and identification of PAOs assisted in understanding the contribution of each isolate to phosphate removal from composite samples of fish pond. Using conventional plating techniques. Since PAOs can store and utilize intracellular carbon polymer as PHAs for development and growth, the isolation process was carried out in shifts of the carbonaceous medium to the absent carbonaceous medium in order to screen and eliminate bacteria which can posses or not such characters. During the screening of polyphosphate accumulating bacteria, 191 isolates were obtained from composite samples of ten provinces collected from Delta Mekong, Vietnam (table 1).

Table 1. The result of isolates in samples obtained from the province of Mekong Delta, Vietnam

\begin{tabular}{lcc}
\hline Sampling Site & Number of samples & Number of isolates \\
\hline Tien Giang & 8 & 25 \\
Ben Tre & 6 & 9 \\
Vinh Long & 6 & 15 \\
Tra Vinh & 6 & 11 \\
Soc Trang & 6 & 29 \\
Hau Giang & 6 & 6 \\
Can Tho & 8 & 19 \\
Kien Giang & 8 & 14 \\
An Giang & 8 & 27 \\
Dong Thap & 8 & 36 \\
Total & $\mathbf{7 0}$ & $\mathbf{1 9 1}$ \\
\hline
\end{tabular}

All the isolates were evaluated for their ability to uptake inorganic phosphate from the medium and accumulate phosphate as poly-P. Results of intracellular poly-P quantity studies conducted on the monocultures are shown in table 2 indicated that the concentration of intracellular poly-P varied from $2 \mathrm{mg} / \mathrm{l}$ to $148.1 \mathrm{mg} / \mathrm{l}$ after 6 days of incubation. About $89 \%$ of the isolates showed phosphate uptake under 
$19 \mathrm{mg} / \mathrm{l}$ and only 21 isolates showed high efficiency to accumulating poly-P from 19.6 to $148.1 \mathrm{mg} / \mathrm{l}$.

Of 21 high poly-P accumulating isolates including 14, 5 and 2 have accumulated poly-P intracellularly from 19.6 to $39.1 \mathrm{mg} / \mathrm{l}, 53.1$ to $92.3 \mathrm{mg} / \mathrm{l}$ and 144.2 to $148.1 \mathrm{mg} / \mathrm{l}$ respectively (table 3 ). All the short listed 21 isolates were chosen in order to describe morphology, stain of the cells and sequence of $16 \mathrm{~S}$ rRNA.

Sixteen isolates were gram-positive and five were gram-negative and therefore formed $76.2 \%$ and $23.8 \%$ respectively (table 3 ). They almost have shaped like a rods and short rods or coccoid, a few of them were slightly curved or straight or curved rods.
Table 2. The concentration of intracellular poly-P

\begin{tabular}{lcc}
\hline Concentration of poly-P $(\mathbf{m g} / \mathrm{l})$ & $\begin{array}{c}\text { Number of } \\
\text { isolates }\end{array}$ & $\begin{array}{c}\text { Proportion } \\
(\%)\end{array}$ \\
\hline $2<$ Concentration of poly-P $<19$ & 170 & 89.0 \\
$19<$ Concentration of poly-P $<50$ & 14 & 7.3 \\
$50<$ Concentration of poly-P $<100$ & 5 & 2.6 \\
$100<$ Concentration of poly-P $<150$ & 2 & 1.1 \\
Total & $\mathbf{1 9 1}$ & $\mathbf{1 0 0}$ \\
\hline
\end{tabular}

Table 3. Polyphosphate accumulating capacity of short listed strains isolated from water of fish-pond

\begin{tabular}{|c|c|c|c|c|}
\hline Isolates & $\begin{array}{l}\text { Cell } \\
\text { morphologies }\end{array}$ & $\begin{array}{l}\text { Colony } \\
\text { morphologies }\end{array}$ & Gram & $\begin{array}{c}\text { cocentration of } \\
\text { intracelllar poly-P } \\
(\mathrm{mg} / \mathrm{I})\end{array}$ \\
\hline AGT004L & Rod, motility & Off- white, pure-white edge, irregular margin & $+\mathrm{ve}$ & 31.1 \\
\hline AGT005L & Rod, motility & Circular, milky, smooth, moist & + ve & 25.8 \\
\hline BTT003L & Rod, motility & Circular, low-convex, off-white, mucoid & + ve & 39.1 \\
\hline BTT006L & Rod, motility & Circular, low-convex, off-white & + ve & 76.1 \\
\hline CTT002L & Rod, motility & Circular, translucent, entire margin & $+v e$ & 53.1 \\
\hline CTT004L & Short rod in pairs, twitching & Circular, small, glistening, smooth, margin entire & -ve & 87.1 \\
\hline DTT001L & Rod, motility & Circular, translucent, pure- white, entire margin & $+v e$ & 36.5 \\
\hline DTT021L & Rod, motility & Mikly, smooth, mucoid, entire-margin & + ve & 38.6 \\
\hline DTT025L & Rod, motility & $\begin{array}{l}\text { Convex, smooth, mucoid, off-white, glistening and entire } \\
\text { edge }\end{array}$ & -ve & 24.9 \\
\hline HGT005L & Irregular rod, slow motility & Circular, convex, yellow, shiny & $+v e$ & 34.4 \\
\hline HGT018L & Rod in simply or pairs & Convex, shiny and smooth, orange pink & + ve & 39.1 \\
\hline KGT004L & Rod or coccoid, slow motility & Circular, small, convex, cream-coloured, & $+v e$ & 32.4 \\
\hline KGT005L & Straight or curved rods, motility & Circular, gray-white, convex, rough & -ve & 73.4 \\
\hline STT011L & Rod, motility & Circular, off-white, pure-white edge, smooth, moist & + ve & 32.4 \\
\hline STT009L & rod, motility & Circular, cream-white, entire edge & $+v e$ & 28.9 \\
\hline TGT013L & Short rod in pairs, twitching & Circular, small, glistening, smooth, margin entire & -ve & 148.1 \\
\hline TGT018L & $\begin{array}{l}\text { Slightly curved or straight nonmotile } \\
\text { rods }\end{array}$ & Circular, convex, bright orange & $+v e$ & 25.5 \\
\hline TVT003L & Straight or curved rods, motility & Convex, smooth, translucent, irregular margin & -ve & 144.2 \\
\hline TVT005L & Short rod, motility & Circular, off-white, pure-white edge, irregular margin & + ve & 19.6 \\
\hline VLT002L & Rod or coccoid, slow motility & Off-white, moist, mucoid & + ve & 92.3 \\
\hline VLT003L & Rod, motility & Circular, off-white, pure-white edge, smooth, moist & $+v e$ & 28.5 \\
\hline
\end{tabular}

Note: AG: An Giang, BT: Ben Tre, CT: Can Tho, DT: Dong Thap, HG: Hau Giang, KG: Kien Giang, ST: Soc Trang, TG: Tien Giang, TV: Tra Vinh, VL: Vinh Long province; +ve: positive, -ve: negative.

\subsection{Electron Microscopy}

To investigate the relationship between the morphological characteristics and ultrastructural cells, the isolates were examined by TEM. Cells taken at 6 days incubation $\left(30^{\circ} \mathrm{C}\right)$ were used for TEM examination. The sectioned bacteria $(70$ $\mathrm{nm}$ ) from these hardened samples contained electron dense cells. We observed a wide range of cell sizes in these samples, and noted that the electron dense bodies mostly occurred in the cells and tended to occupy the whole cell.

All isolates contained opaque granules, which could be unambiguously identified as poly-P granules. Different isolates grown in liquid culture, shown remarkable differences in the maximum sizes of granules. Strain TVT003L (Figure 2 [A1,A2]) was found to have small granules of electron dense poly-P dispersed throughout the cells. Cells of strain TGT018L (Figure 2 [B1,B2]) contained both central large granules rather than small granules dispersed throughout the cells as well as normal cells. Isolate TGT013L containing high amounts of poly-P shown electron dense in almost all cells (Figure $2[\mathrm{C} 1, \mathrm{C} 2]$ ). These 
findings show a correlation of the different poly-P concentration obtained by quantification of intracellular poly-P and sizes of the granules obtained by electron microscopy. Strain TGT013L (Figure 2 [C1]) had electron transparent inclusions (glycogen or PHA).

\subsection{Identity and Phylogenetic Analysis of PAOs}

The determination of nearest phylogenetic neighbor sequences for 16S rRNA gene sequences of the twenty-one isolated by the BLAST search program showed that they grouped into four separate clade including 11, 5, 3, 2 sequences belonged to the class Bacilli, Actinobacteria, Gamma-proteobacteria and Beta-proteobacteria, respectively. Their phylogenetic relationship was shown in the phylogenetic tree (Figure 3).
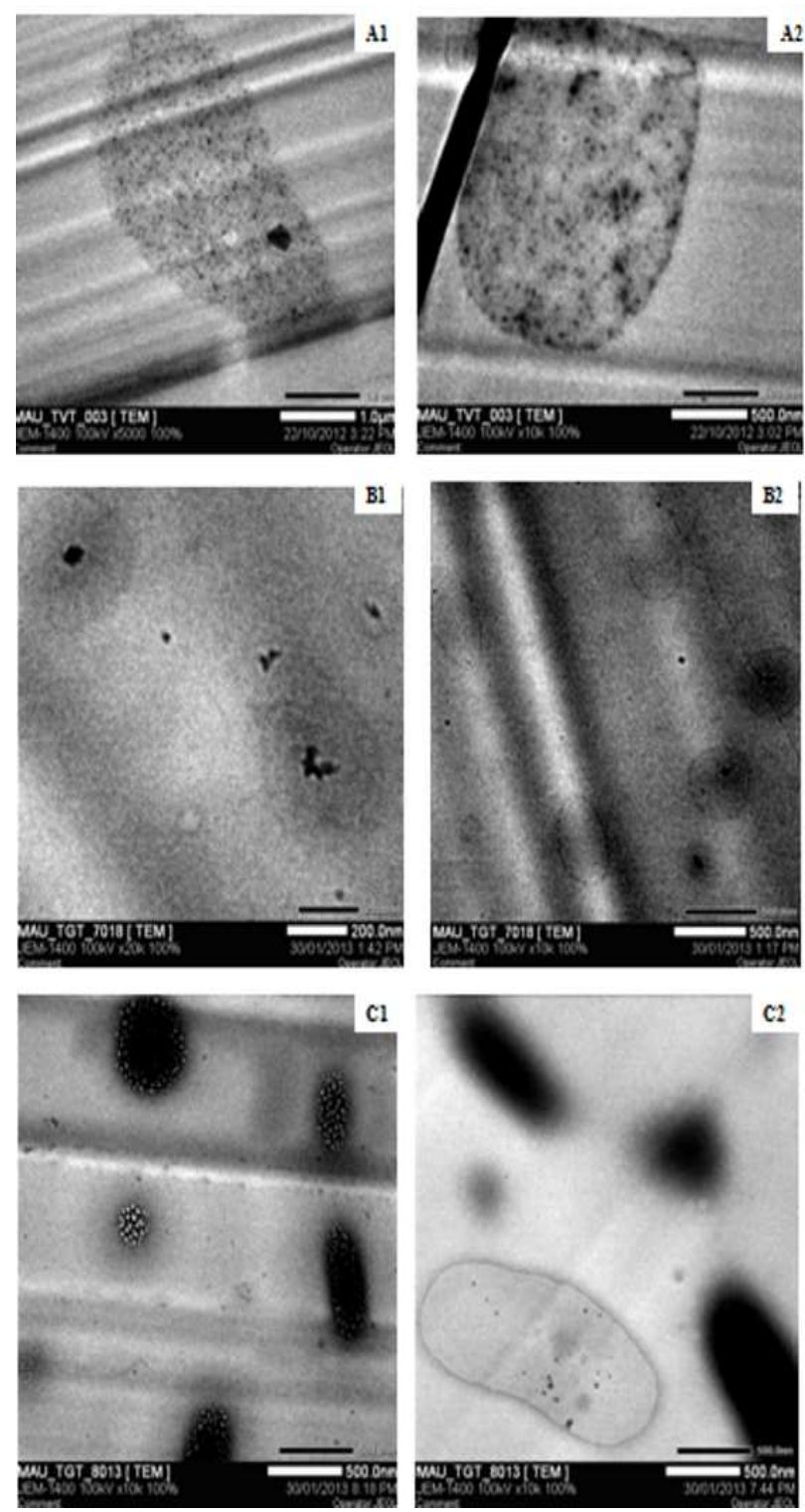

Figure 2. TEM electron micrographs of cells. (A1) curved rod-shaped cell of TVT003L isolated (x5000), (A2) straight rod-shaped cell of strain TVT003L (x10,000), (B1, B2) rod-shaped cell of strain TGT018L (x20,000, 10,000 respectively), (C1, C2) rod-shaped cell of strain $T G T 013 L$ $(x 10,000)$.
Clade 1 as the most abundant strains (eleven) was related to Bacilli within family Bacillaceae. Of these eleven strains, five (DTT021L, DTT001L, BTT003L, AGT005L and STT009L) were related to sequences of Bacillus megaterium (with 99, 99, 97, 99 and 98\% identity; respectively), and three strains (VLT003L, STT011L and BTT006L) were related to sequences of $B$. aryabhattai (with 98, 99 and $98 \%$ identity; respectively) and two strains (AGT004L and CTT002L) were related to sequences of Bacillus sp. (with 99 and $98 \%$ identity, respectively). The remaining strain TVT005L was related with $B$. ginsengihumi with $98 \%$ identity.

Clade 2 as the second abundant strains (five) was affiliated with Actinobacteria. It is found that three stains HGT005L, KGT004L and VLT002L belonging to family Micrococcaceae were related to Arthrobacter sp. (98 to $99 \%$ identity) and Mycobacterium phocaicum (98\% identity) within family Mycobacteriaceae and Gordonia polyisoprenivorans $\quad(98 \%$ identity) within family Gordoniaceae.

Clade 3 was affiliated with three strains belonging to two families. Of these three strains, two strains TGT013L and CTT004L were related to Acinetobacter radioresistens (99\% identity) and Acinetobacter sp (98\% identity), respectively within family Moraxellaceae, and strain was related to Stenotrophomonas maltophilia (99\% identity) within family Xanthomonadaceae.

Clade 4 related to Cupriavidus sp. (99\% identity) and Burkholderia vietnamiensis (98\% identity) within family Burkholderiaceae (Table 4).

In recent years, molecular techniques have been used increasingly to characterize sludge microbial community structure and to classify PAOs based on their taxonomic affiliations. The application of these techniques has shown that EBPR sludge is composed of diverse bacterial phyla, including Proteobacteria, Gram positive high $\mathrm{G}+\mathrm{C}$ Actinobactera, Gram positive low $\mathrm{G}+\mathrm{C}$ Firmicutes, Bacteroidetes, Planctomycetes $(5,31,32,33)$. In this study, a $16 \mathrm{~S}$ rRNA sequences was constructed to characterize the microbial composition inside the catfish pond. Results of $16 \mathrm{~S}$ rRNA sequences of 21 isolated and compared with related sequences retrieved from GenBank shown in Figure 3. These strains represented different phylogenetic groups from the Gram-positive low $\mathrm{G}+\mathrm{C}$ group liked Bacilii (52.4\%), Gram-positive high $\mathrm{G}+\mathrm{C}$ as Actinobacteria (23.8\%), Gamma-proteobacteria (14.3\%) and Beta-proteobacteria (9.5\%) (Figure 4). Bacillus isolates dominated in samples.

Despite of the variations of poly-P content was observed in this study. The excess poly-P accumulating ability of bacteria had been reported by possible PAOs such as Acinetobacter $(34,35,16 ; 26 ; 25)$, Stenotrophomonas and Burkholderia (28). Results illustrated in table 3 indicate that the highest phosphate accumulators are representative of gram-negative bacteria. The results reveal that amongst the gram-negative, of the gram-negative organisms isolated Acinetobacter sp. were formed $9.5 \%$. 
Historically, it has been thought that bacteria of the Gamma-proteobacteria, dominate phosphate removing activated sludge populations. However, non-culture dependent methods (36), fluorescent in situ hybridization probes (37) and 16S rRNA sequences of the bacterial population in sludge samples obtained from SBRs (38) indicated that Acinetobacter spp. were present in small proportions in activated sludge (approximately 3 to 6\%); Wagner et al. (1994) using oligonucleotide probes specific for Acinetobacter spp. and using $16 \mathrm{~S}$ rRNA sequences in this study reported that Acinetobacter spp. formed 8 to $10 \%$ of the bacterial community in sludge (37). These results correlate with the findings above. Besides Acinetobacter sp. of the gram-negative, Stenotrophomonas sp., Burkholderia sp., Cupriavidus sp., constituted $4.76 \%$ each of the total gram-negative isolates. All Gamma-proteobacteria isolates showed the propensity to accumulate phosphate, but the highest was shown by Acinetobacter radioresistens TGT013L (148.1 mg/l) followed by Acinetobacter sp. CTT004L (87.1 $\mathrm{mg} / \mathrm{l})$ and Stenotrophonas maltrophia KGT005L (73.4 mg/l) (Table 3). In the remaining negative class Beta-proteobaceria, Burkholderia vietnamiensis TVT003L shown to accumulate poly-P highly $(144.2 \mathrm{mg} / \mathrm{l})$ followed by Cupriavidus sp. DTT025L (24.9 mg/l).

Table 4. Phylogenetic affiliations of isolates on the basis of $16 S$ rDNA gen sequences by using BLAST progam in the GenBank database based on sequence similarity

\begin{tabular}{|c|c|c|c|}
\hline Taxanomic group and strain & Closest species relative & Similarity (\%) & Length/gap (bp) \\
\hline \multicolumn{4}{|l|}{ Bacilli } \\
\hline \multicolumn{4}{|l|}{ Bacillaceae } \\
\hline DTT021L & Bacillus megaterium (JQ229803) & 99 & $1249 / 1$ \\
\hline DTT001L & Bacillus megaterium (JQ229803) & 99 & $1227 / 4$ \\
\hline BTT003L & Bacillus megaterium (DQ365564) & 97 & $923 / 6$ \\
\hline AGT005L & Bacillus megaterium (FJ976535) & 99 & $1274 / 5$ \\
\hline STT009L & Bacillus megaterium (FJ976535) & 98 & $1304 / 8$ \\
\hline VLT003L & Bacillus aryabhattai (HQ908708) & 98 & $1344 / 12$ \\
\hline STT011L & Bacillus aryabhattai (JN084155) & 99 & $1248 / 5$ \\
\hline BTT006L & Bacillus aryabhattai (HQ242767) & 98 & $1352 / 7$ \\
\hline AGT004L & Bacillus sp. (HQ024491) & 99 & $1202 / 4$ \\
\hline CTT002L & Bacillus sp. (DQ275185) & 98 & $1345 / 15$ \\
\hline TVT005L & Bacillus ginsengihumi (FJ357590) & 98 & $1275 / 8$ \\
\hline \multicolumn{4}{|l|}{ Actinobacteria } \\
\hline \multicolumn{4}{|l|}{ Micrococcaceae } \\
\hline HGT005L & Arthrobacter sp. (AB638330) & 98 & $1150 / 6$ \\
\hline KGT004L & Arthrobacter sp. (EU571174) & 99 & $1226 / 3$ \\
\hline VLT002L & Arthrobacter protophormiae (AB210984) & 98 & $1366 / 8$ \\
\hline \multicolumn{4}{|l|}{ Mycobacteriaceae } \\
\hline TGT018L & Mycobacterium phocaicum (EF551407) & 98 & $1053 / 5$ \\
\hline \multicolumn{4}{|l|}{ Gordoniaceae } \\
\hline HGT018L & Gordonia polyisoprenivorans (DQ154925) & 98 & $1155 / 7$ \\
\hline \multicolumn{4}{|l|}{ Gamma-proteobacteria } \\
\hline \multicolumn{4}{|l|}{ Moraxellaceae } \\
\hline TGT013L & Acinetobacter radioresistens (GU145275) & 99 & $1277 / 7$ \\
\hline CTT004L & Acinetobacter sp. (AJ633641) & 98 & $1268 / 7$ \\
\hline \multicolumn{4}{|l|}{ Xanthomonadaceae } \\
\hline KGT005L & Stenotrophomonas maltophilia (AJ295671) & 99 & $784 / 0$ \\
\hline \multicolumn{4}{|l|}{ Beta-proteobacteria } \\
\hline \multicolumn{4}{|l|}{ Burkholderiaceae } \\
\hline TVT003L & Burkholderia vietnamiensis (JF922108) & 98 & $1182 / 12$ \\
\hline DTT025L & Cupriavidus sp. (AB266608) & 99 & $1148 / 2$ \\
\hline
\end{tabular}




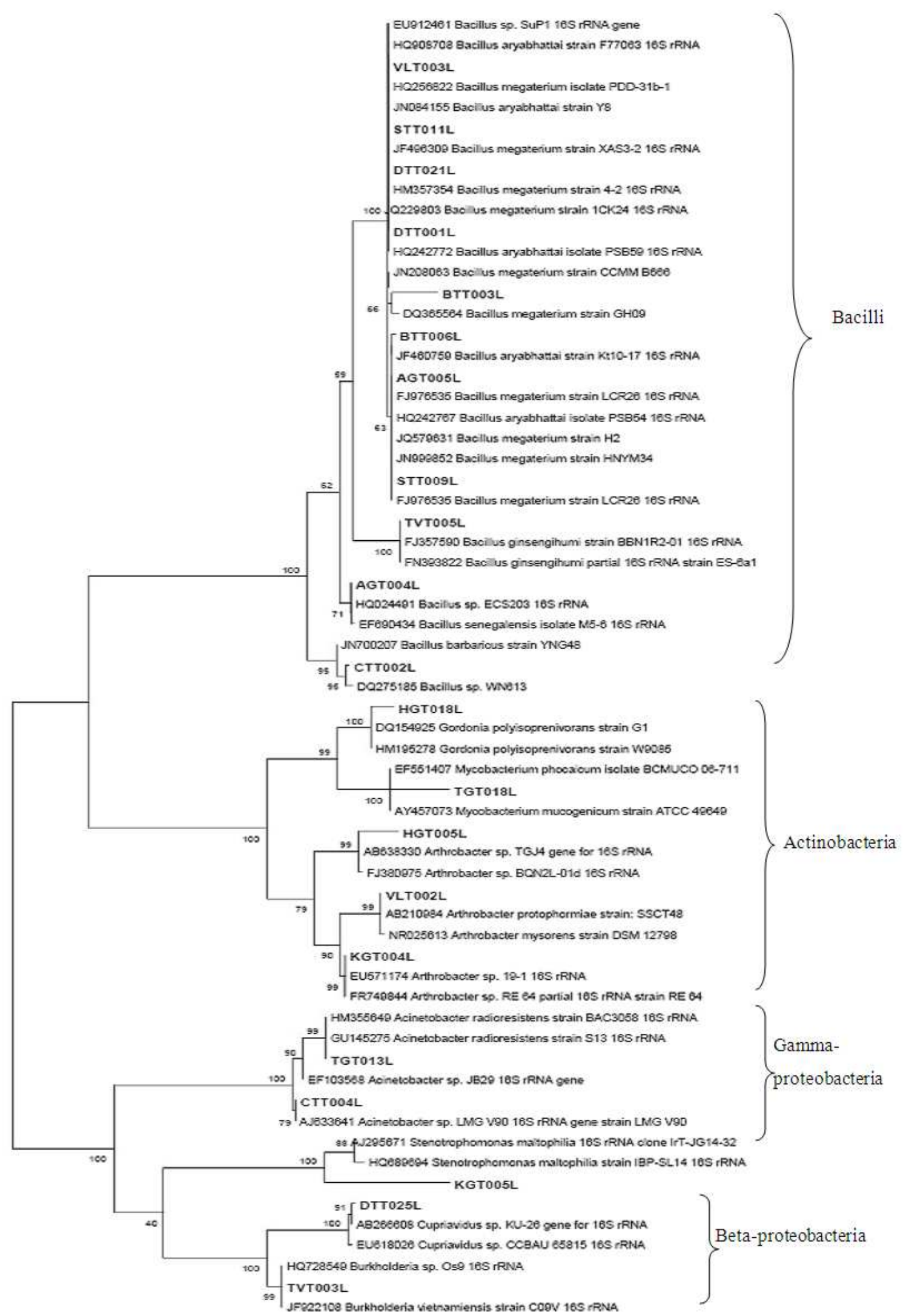

Figure 3. Phylogenitic tree for partial 16S rRNA gene sequences from 21 isolates by using universal primers (27f and 1492r) showing relationships between representative strains along with related sequences retrieved from GenBank. The numbers at the nodes indicate the levels of bootstrap support (\%) based on a Maximum Likelihood analysis of 500 re-sampled datasets. The scale bar indicates the phylogenetic distance corresponding to 5 changes per 100 bases. 


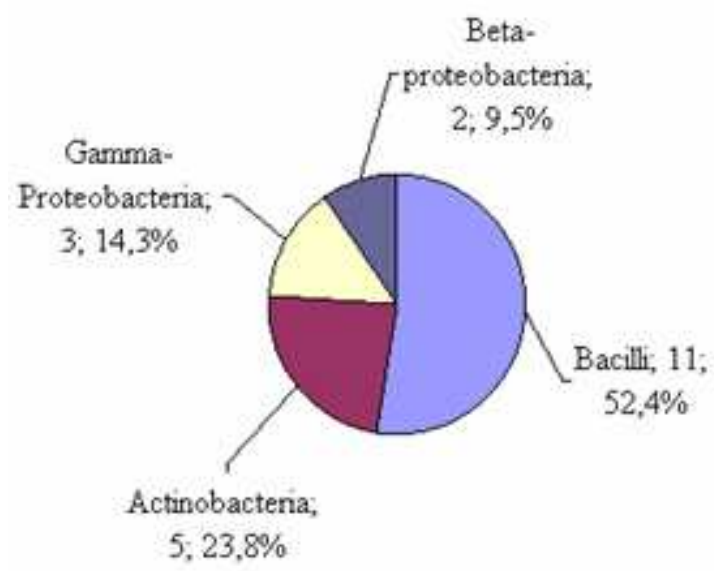

Figure 4. The proportion of clade and recombinant of gram-positive genera isolated from water of fish pond

Bond et al., (1999) and Liu et al., (2001) using the FISH technique reported that gram-positive bacteria with high $\mathrm{G}+\mathrm{C}$ contents were dominant $35 \%$ and $17.9 \%$ respectively in the activated sludge system $(5,39)$. Szabó et al., (2011) found that the culturable fraction of a number of surface sediment bacterial communities from two basins with differing trophic states within Lake Balaton (Hungary) was dominated by Firmicutes, Actinobacteria, Alpha-proteobacteria. The majority of the strains showed excess poly-P accumulation (40). Gram-positive bacteria with high $\mathrm{G}+\mathrm{C}$ contents have also been observed as dominant members of a phosphate removing activated sludge community as determined by a non-culture dependent method (fluorescent in situ hybridization), and it was suggested that bacteria belonging to this group may have been responsible for the observed phosphate removal (37). Results illustrated in table 3 indicate the predominance of gram-positives in the sludge, found to be $76.2 \%$ of the total isolated poly-P population. Figure 4 also indicates that Bacillus sp. were the predominant gram-positives, forming $52.4 \%$ of the gram-positive population isolated from composite samples followed by Arthrobacter sp., Mycobacterium phocaicum TGT018L and Gordonia polyisoprenivorans HGT018L forming 14.3, 4.6 and 4.6\%, respectively. Of the Bacillus sp. (11 strains), it is found that two strains Bacillus aryabhattai BTT006L and Bacillus sp. CTT002L showed higher poly-P storage than others approximately 76.1 and $53.1 \mathrm{mg} / \mathrm{l}$ respectively. Eight strains included Bacillus megaterium (BTT003L, DTT021L, DTT001L, AGT005L, STT009L) and B. aryabhattai (STT011L, VLT003L) and Bacillus sp. AGT004L showed to accumulate poly-P ranging from 25.8 to $39.1 \mathrm{mg} / \mathrm{l}$. The remaining strain $\mathrm{B}$. ginsengihumi showed the lowest accumulating poly-P approximately $19.6 \mathrm{mg} / \mathrm{l}$. It is demonstrated that Bacillus spp. accounted for the highest of strains, however, the poly-P concentration of cell differed remarkably among relatives of different species. In the class Actinobacteria, poly-P accumulation was assessed among Arthrobacter, Gordonia and Mycobacterium. Arthrobacter sp. has previously been characterized as PAOs and was shown to have high phosphate uptake affinity (41). Of the Arthrobacter, it is found that A. protophormiae VLT002L shown to take up and store poly-P highly approximately $92.3 \mathrm{mg} / \mathrm{l}$, followed by Arthrobacter sp. HGT005L and Arthrobacter sp. KGT004L shown to accumulate lower poly-P about 34.4 and $32.4 \mathrm{mg} / \mathrm{l}$, respectively. In addition, Mycobacterium and Gordonia was also posible PAOs candidate $(17,42)$. The results showned that $\mathrm{M}$. phocaicum TGT018L and G. polyisoprenivorans HGT018L accumulated poly-P about 25.5 and $39.1 \mathrm{mg} / 1$, respectively.

\section{Conclusions}

This results showed that the abundance of cultivated PAOs and the diversity of bacteria communities in water and sludge of intensive catfish ponds. Association of poly-P staining and the poly-P concentration test results suggested that excess poly-P accumulation and store formed intracellular poly-P granules. Although Acinetobacter sp. and Burkholderia sp. in low numbers, their capacity to accumulate poly-P intracellularly was the highest amongst all the isolates. Furthermore, this study showed the importance of PAOs among Bacilli, Actinobacteria, Beta-proteobacteria and Gamma-proteobacteria in composit samples of intensive catfish ponds. It is implied that identified isolates may be representative of PAOs inside the catfish ponds in the Mekong Delta, Vietnam. Further, the researches will focus on isolated collection and application for treatment soluble phosphate removal in waste of catfish pond.

\section{Acknowledgements}

This work was supported by Ministry of Science and Technology, Vietnam Government. The author thanks the helpness of Biotechnology MSc. students and technicians in the Environment Microbiology Laboratory, Biotechnology R\&D Institute, Can Tho University, Vietnam.

\section{References}

[1] N. P. van Zalinge, P. Degen, P. Pongsiri, S. Nuov, J. G. Jensen, V. H. Nguyen, X .Choulamany, "The Mekong River System" In: R. L. Welcomme, T. Petr (Eds.), Proceedings of the Second International Symposium on the Management of Large Rivers for Fisheries,", Volume 1. FAO Regional Office for Asia and the Pacific, Bangkok, Thailand, RAP Publication 2004/16, pp. 335-357.

[2] Sub-Institute of Water Resources Planning, "Analysis of sub-area $10 \mathrm{~V}$ basin development plan," Viet Nam National Mekong Committee, Ho Chi Minh City, November 2003, 87 pp.

[3] Lam T. Phan, Tam M. Bui, Thuy T. T. Nguyen, Geoff J. Gooley, Brett A. Ingram, Hao V. Nguyen, Phuong T. Nguyen, S. S. De Silva, "Current status of farming practices of striped catfish, Pangasianodon hypophthalmus in the Mekong Delta, Vietnam,” Aquaculture 296, 2009, pp. 227-236.

[4] S. S. De Silva, Brett. A. Ingram, Phuong T. Nguyen, Tam M. Bui, Geoff J. Gooley, Giovanni M. Turchini, "Estimation of 
Nitrogen and Phosphorus in Effluent from the Striped Catfish Farming Sector in the Mekong Delta, Vietnam," Ambio, Vol. 39(7), published online 2010 July, pp. 504-514.

[5] P. L. Bond, R. Erhart, M. Wagner, J. Keller, L. L. Blackall, "Identification of some of the the major groups of bacteria in efficient anf non-efficient biolical phosphorus removal activated sludge systems," Appl. Environ. Microbiol., Vol. 65(9), 1999, pp. 4077-4088.

[6] T. Mino, M. C. M. Van Loosdrecht and J. J. Heijnen, "Microbiology and biochemistry of the enhanced biological phosphate removal process," Water Res., Vol. 32, 1998, pp. 3193-3207.

[7] A. Oehmen, P. C. Lemos, G. Carvalho, Z. Yuan, J. Keller, L. L. Backall, M. A. M. Reis, "Advances in enhanced biological phosphorus removal: from micro to macro scale," Water Research, Vol. 41, 2007, pp. 2272-2300.

[8] R-J. Seviour, T. Mino, M. Onuki, "The microbiology of biological phosphorus removal in activated sludge systems," FEMS Microbiology Reviews, Vol. 27, 2003, pp. 99-127.

[9] K. Nakamura, K. Masuda., and E. Mikami, "Isolation of a new type of polyphosphate accumulating bacteria and its phosphate removal characristics," Journal of fermentation and bioengineering, Vol. 71, 1991, pp. 258-263.

[10] Y. Ubukata and S. Takii, "Induction ability of excess phosphate accumulation for phosphate removing bacteria," Water Res., Vol. 28, 1994, pp. 247-249.

[11] G. W. Fuhs and M. Chen, "Microbiological basis of phosphate removal in the activated sludge process for treatment of wastewater," Microbial. Ecol., Vol. 2, 1975, pp. 119-138.

[12] G. R. Crocetti, P. Hugenholtz, P. L. Bond, A. Schuler, J. Keller, D. Jenkings, and L. L. Blackall, "Identification of Polyphosphate-Accumulating Organisms and Design of 16S rRNA-Directed Probes for Their Detection and Quantitation," Applied and environmental microbiology, Vol. 66(3), 2000, pp. $1175-1182$.

[13] Y. Kong, J. L. Nielsen and P. H. Nielsen, "Identify ecophysiology of uncultured Actinobacterial polyphosphate accumulating organisms in full scale enhanced biological phosphorus removal plants," Applied and Environmental Microbiology, Vol. 71(7), 2005, pp. 4076-4085.

[14] H. T. T. Nguyen, L. V. Quy, A. A. Hansen, J. L. Nielsen and H. Nielsen, "High diversity and abundence of putative polyphosphate accumulating Tetrasphaera related in activated sludge systems," Microbiol Ecol., Vol. 76, 2011, pp. 256-267.

[15] G. Auling, F. Pilz, H-J. Busse, S. Karrash, M. Streichan and G. Schon, "Analysis of the polyphosphate accumulating microflora in phosphorus eliminating, anaerobic-aerobic activated sludge systems by using Diaminopropane as a biomarker for rapid estimation of Acinetobacter spp," Applied and Environmental Microbiology, 1991, pp. 3585-3592.

[16] M. Sidat, F. Bux and H. C. Kasan, "Polyphosphate accumulation by bacteria isolated from activated sludge," Water SA., Vol. 25(2), 1999, pp. 175-179.

[17] K. D. McMahon, M. A. Dojka, N. R. Pace, D. Jenkins and J. D. Keasling, "Polyphosphate kinase genes from activated sludge carrying outenhanced biological phosphorus removal," Appl. Environ. Microbiol., Vol. 68, 2002, pp. 4971-4978.

[18] S-J. Lee, Y-S. Lee, Y-C. Lee and Y-L. Choi, "Moclecular chracterization of polyphosphate (PolyP) operon from Serratia marcescens," Basic Microbial., Vol. 46(2), 2006, pp. 108-115.

[19] J. M. Kim, H. J. Lee, S. Y. Kim, J. J. Song, W. Park and C. O. Jeon, "Analysis of the Fine-scale population structure of "Candidatus accumulibacter phosphatis" in enhanced biological phosphorus removal sludge, using flurescence in situ hybridization and flow cytometric sorting," Applied and environmental microbiology, Vol. 76(12), 2010, pp.3825-3835.

[20] S. He, D. L. Gall, and K. D. McMahon, "Candidatus Accumulibacter Population Structure in Enhanced Biological Photphorus Removal Sludges as Revealed by Polyphosphate Kinase Genes," Applied and Environmental Microbiology, Vol. 73, 2007, pp. $5865-5874$.

[21] L. S. Buzoleva, A. M. Krivosheeva, A. S. Isachenko, L. M. Somova and G. P. Somov, "Effect of temperature on synthesis of polyphosphate in Yersinia pseudotuberculosis and Listeria monocytogenes under starvation conditions," Biochemistry (Moscow), Vol. 71(4), 2006, pp. 473-44.

[22] S. Eixler, U. Selig and U. Karsten, "Extraction and detection methods for polyphosphate strorage in autotrophic planktonic organisms," hydrobiologia, Vol. 533(1). 2005, pp. 135-143.

[23] G. J. F. Smolders, J. van der Meij, M. C. M. van Loosdrecht and J. J. Heijnen, "Stoichiometric model ofthe aerobic metabolism of the biological Prusremoval process," Biotech. Bioeng., Vol. 44, 1994, pp. 837-848.

[24] J. Murphy \& J. P. Riley, "A modified single solution method for the determination of phosphate in natural waters," Analytica Chimica Acta 27, 1962, pp. 31-36.

[25] C. D. Boswell, R. E. Dick, H. Eccles and L. E. Macaskie, "Phosphate uptake and release by Acinetobacter johnsonii in continuous culture and coupling of phosphate release to heavy metal accumulation," Journal of industrial microbiology and biotechnology, Vol. 26, 2001, pp. 333-340.

[26] E. H. E. Carr, S. Feng, A. Hoogenraad, R. Croome, J. Soddell, K. Lindrea and R. Seviour, "RAPD-PCR typing of Acinetobacter isolates from activated sludge systems designed to remove phosphorus microbiologically," Journal of Applied microbiology, Vol. 90, 2001, pp. 309-319.

[27] D. J. Lane, "16S/23S rRNA sequencing. Nucleic acid techniques in bacterial systematics," E. Stackebrandt and M. Goodfellow, eds. New York, NY, John Wiley and Sons: 115-175, 1991.

[28] V. Ivanov, V. Stabnikov, W. Q. Zhuang, J. H. Tay and S. T. L. Tay, "Phosphate removal from the returned liquor of municipal wastewater treatment plant using iron-reducing bacteria," Applied Microbiology, Vol. 98, 2005, pp. $1152-1161$.

[29] K. Tamura, D. Peterson, N. Peterson, G. Stecher, M. Nei and S. Kumar, "MEGA5: Molecular Evolutionary Genetics Analysis Using Maximum Likelihood, Evolutionary Distance, and Maximum Parsimony Methods," Mol. Biol., Vol. 28(10), 2011, pp. 2731-2739. 
[30] G. M. Garrity, "Bergey's Manual of Systematic Bacteriology, 2nd edition (New York: Springer), 2005.

[31] H. Tamaki, Y. Sekiguchi, S. Hanada, K. Nakamura, N. Nomura, M. Matsumura and Y. Kamagata, "Comparative analysis of bacterial diversity in freshwater dediment of a shallow eutrophic lake by molecular and improved cultivation based techniques," Applied and environmental microbiology, Vol. 71(4), 2005, pp. 2162-2169.

[32] J. Ahn, S. Schroeder, M. Beer, S. Mcllroy, R. C. Bayly, J. W. May, G. Vasiliadis and R. J. Seviour, "Ecology of the Microbial Community removing Phosphate from Wastewater under Continuously Aerobic Conditions in a Sequencing Batch Reactor," Applied and Environmental Microbiology, Vol. 73, 2007, pp. 2257-2270.

[33] S. Gloess, H-P. Grossart, M. Allgaier, S. Ratering and M. Hupfer, "Use of Laser microdissection for phylogenetic characterization of polyphosphate accumulating bacteria," Applied and Environmental Microbiology, Vol. 74(13), 2008, pp. 4231-4235.

[34] H. Ohtake, K. Takahashi, Y. Tsuzuki and K. Toda, "Uptake and release of phosphate by a pure culture of acinetobacter calcoaceticus," Water Res., Vol. 19(12), 1985, pp. $1587-1594$.

[35] K. Bark, A. Sponner, P. Kämpfer, S. Grund and W. Dott, "Differences in polyphosphate accumulation and phosphate adsorption by Acinetobacter isolate from wastwater producing polyphosphate: AMP phosphotransferase," Wat. Res., Vol. 26(10), 1992, pp. 1379-1388.

[36] A. Hiraishi, K. Masamune and H. Kitamura, "Characterization of the Bacterial Population Structure in an Anaerobic-Aerobic Activated Sludge System on the Basis of
Respiratory Quinone Profiles,” Applied and Environmental microbiology, Vol. 55(4), 1989, pp. 897-901.

[37] M. Wagner, R. Erhart, W. Manz, R. Amann, H. Lemmer, D. Wedi and K. H. Schleifer, "Development of an rRNA-targeted oligonucleotide probe specific for the genus Acinetobacter and its application for in situ monitoring in activated sludge," Appl. Environ. Microbiol, Vol. 60(3), 1994, pp. 792-800.

[38] P. L. Bond, P. Hugenholtz, J. Keller And L. L. Blackall, "Bacterial community structure of phosphate removing and non-phosphate removing activated sludges from sequencing batch reactor," Applied and Environmental Microbiology, Vol. 61(5), 1995, pp. 1910-1916.

[39] W-T. Liu, A. T. Nielsen, J-H. Wu, Y. C-S. Tsai, "Matsuo and S. Molin. In situ identification of polyphosphate and polyhydroxyalkanoate accumulating traits for microbial populations in a biological phosphorus removal process," Environmental Microbiology, Vol. 3(2), 2001, pp. 110-122.

[40] G. Szabó, B. Khayer, A. Rusznyák, I. Tátrai, G. Dévai, K. Márialigeti and A K. Borsodi, "Seasonal and spatial variability of sediment bacterial communities inhabiting the large shallow Lake Balaton," Hydrobiologia, Vol. 663, 2011, pp. 217-232.

[41] M. Shoda, T. Ohsumi and S. Udaka, "Screening for high phosphate accumulating bacteria," Agric. Biol. Chem.,Vol. 44(2), 1980, pp. 319-324.

[42] M. Beer, H. M. Stratton, P. C. Griffiths and R. J. Seviour, "Which are the polyphosphate accumulating organisms in full scale activated sludge enhanced biological phosphate removal system in Austalia?," Applied of Microbiology, 100, 2006, pp. 233-243. 